\title{
ガラスのマイクロプレス成形に関する数值シミュレーション
}

\section{Numerical simulation of micro press molding of glass}

\author{
○小寺力 (信州大院) 荒 井 政大 (信州大) \\ 井野友博 (信州大院) 安井 学 (神奈川県産業技術センター) \\ 伊藤 寛明 (信州大)
}

Tsutomu KODERA, Graduate Student, Shinshu University

Masahiro ARAI, Shinshu University, 4-17-1, Wakasato, Nagano City, Japan

Hiroaki ITO, Shinshu University, 4-17-1, Wakasato, Nagano City, Japan

Tomohiro INO, Graduate Student, Shinshu University

Manabu YASUI, Kanagawa Industrial Technology Center

Key Words: Glass micro press, Thermo-Viscoelasticity, Creep test, Finite element method

\section{1. 緒 論}

近年の光学分野の発展にともない，微細構造デバイスへの期 待が高まっている.ガラスや樹脂の表面にマイクロ・ナノスケー ルの微細構造を付与することにより，これまでにない新たな光 学特性の発現が期待できる. 現在, 微細パターンの製造方法と して，リソグラフィを利用した半導体プロセスが一般的に用い られているが，製造工程が複䧱であり，装置も高価である。ま た，単品生產となるため，コス卜高である。これらの問題を解 決する手法として，金型を用いた高温プレス成形が注目されて いる．高温プレス成形は，所望の形状に加工された金型形状を ガラスや樹脂に転写させる技術であり，光学特性の優れたガラ ス材表面に溝形状やドット形状の周期構造を転写することによ り, 光通信用の光導波路やマイクロレンズアレイといった様々 な用途の光学デバイスを，安価かつ容易に製造できる。

しかしながら，ガラスは応力とひずみの関係が時間と温度に 依存する熱粘弾性体であるため，プレス成形により所望の形状 を得ることは非常に困難である。また，成形温度や成形圧力， 冷却時間など，考慮すべきパラメータが多く，実験により最適 成形条件を探索することは多くのコストと労力が必要となる.

そこで本研究では, 有限要素解析を用いてガラスのマイクロ プレス成形の最適成形条件を評価することを目的としている. 数值シミュレーションに先立ち、様々な温度環境下での一軸圧 縮クリープ試験を実施し、ガラス材料の熱粘弾性特性の導出を 行った。得られた熱粘弾性特性を用い矩形溝形状のマイクロ成 形に関する数值シミュレーションを実施し、実際の成形試験結 果との比較を行った。

\section{2. 熱粘弾性特性}

本研究では，ガラス材料を線形熱粘弾性体として取り扱う. 一軸压縮クリープ試験によりクリープ関数を求め, 緩和弾性係 数を導出した ${ }^{(1)}$ 。な扔, 線形熱粘弾性体には, 時間-温度換算則 が成り立つことが知られている。この法則を用い，任意温度で の緩和弾性係数を対数時間軸上で平行移動させることにより, 基準温度での緩和弾性係数であるマスターカーブに一致させる ことができる。このときの平行移動量をシフトファクターと呼 ぶ. 本研究で用いた，ガラス材 D 263 およびPYREX の諸特性 を Table 1 に示す。な扮解析に用いるため, 得られたマスター カーブをFig.1に示すような 3 要素 Maxwell モデルを用いて

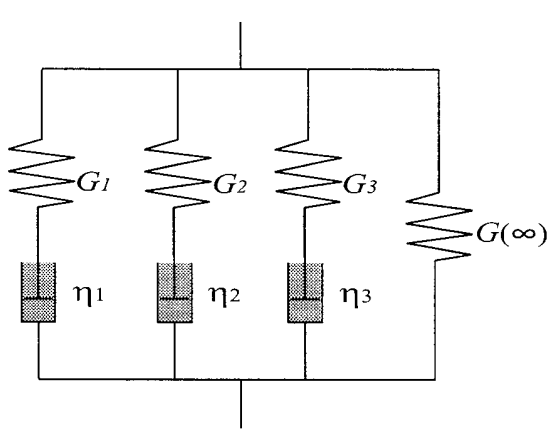

Fig.1 Maxwell model

Table 1 Specification of the glass specimen

\begin{tabular}{|l|c|c|}
\hline Material of glass & D263 & PYREX \\
\hline Glass transition temp. $\left[{ }^{\circ} \mathrm{C}\right]$ & 557 & 560 \\
\hline Young's modulus $[\mathrm{GPa}]$ & 72.9 & 65.6 \\
\hline Poisson's ratio & 0.21 & 0.20 \\
\hline Coefficient of thermal expansion $[\mu / \mathrm{K}]$ & 7.2 & 3.2 \\
\hline
\end{tabular}

Table 2 Coefficient of Maxwell model

\begin{tabular}{|c|c|c|c|c|}
\hline Coefficient [GPa] & $G_{1}$ & $G_{2}$ & $G_{3}$ & $G_{\infty}[\mathrm{MPa}]$ \\
\hline D263 & 7.455 & 22.364 & 0.301 & 0.42 \\
\hline PYREX & 6.750 & 6.750 & 13.770 & 0.41 \\
\hline Relaxation Time [Ms] & $\lambda_{1}$ & $\lambda_{2}$ & $\lambda_{3}$ & \multicolumn{1}{|}{} \\
\cline { 1 - 4 } D263 & 0.44 & 0.47 & 0.54 \\
\cline { 1 - 4 } PYREX & 0.48 & 0.52 & 0.58 \\
\cline { 1 - 3 }
\end{tabular}

近似した。これにより得られた Maxwell モデルに扮けるバネ 定数 $G_{i}$ 扩よび緩和時間 $\lambda_{i}=\eta_{i} / G_{i}$ を Table 2 に示す.

\section{3. マイクロプレス成形}

3 -1 マイクロプレス成形試験ガラス材料として, D263 および PYREX を用いてマイクロプレス成形試験を実施した。 金型には，東海カーボン 製のグラッシーカーボンを用い，ダ 


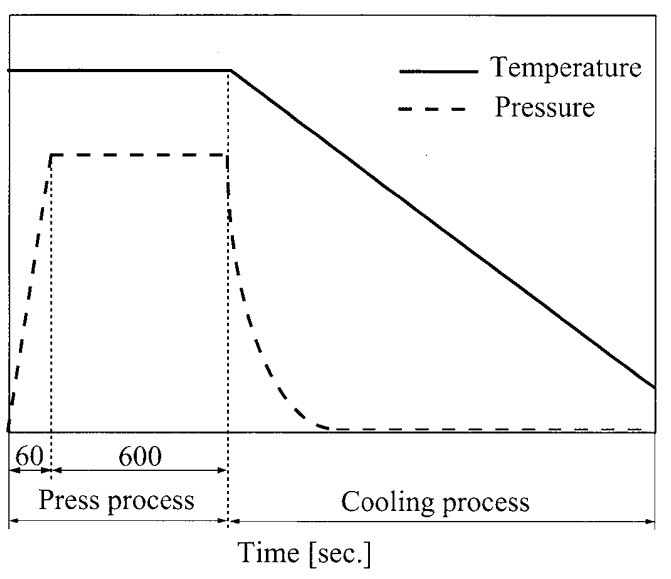

Fig.2 Forming sequence

Table 3 Testing condition of glass micro press

\begin{tabular}{|c|c|c|}
\hline Glass Type & D263 & PYREX \\
\hline Temperature [ $\left.{ }^{\circ} \mathrm{C}\right]$ & $580,600,610,620$ & $630,640,650,660,670,680$ \\
\hline Load [N] & $700 \sim 800$ & $700 \sim 800$ \\
\hline Press time [sec.] & 600 & 600 \\
\hline
\end{tabular}

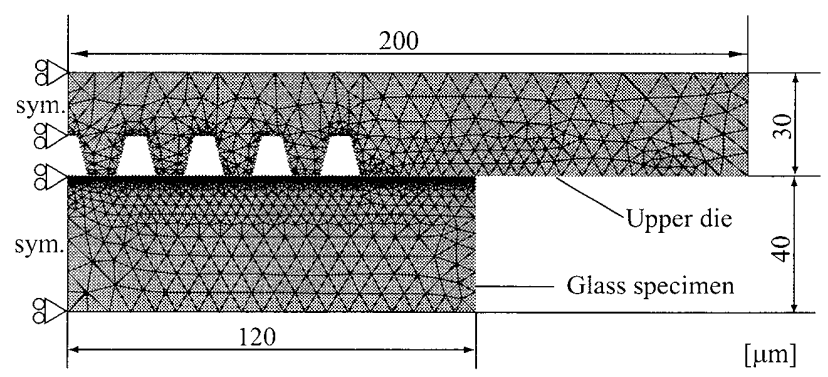

Fig.3 FEM model of glass micro press

イシングにより溝幅 $10[\mu \mathrm{m}]$, ピッチ $10[\mu \mathrm{m}]$, 深さ $12[\mu \mathrm{m}]$, 溝 数 100 本のラインアンドスペースの加工を施した。 プレス成形 試験には，エンジニアリングシステム 製ホットエンボス装置 (ASHE0201) を用い，Fig.2に示す成形シーケンスに従い，真 空中にてプレス成形を行った。各種プレス成形条件を Table 3 に示す。な扮却工程において強制冷却は行っておらず，上型 を固定した状態において自然冷却を行っている。

3.2 数值解析 クリープ試験により得られた熱粘弾性特 性を用いてマイクロプレス成形解析を実施した。本研究で用い た解析モデルを Fig.3 に示す．成形シーケンスは，プレス成形 時と同様（Fig.2）としたが，冷却工程については，金型を变位 制御することにより金型とガラスの離型を行った。また，前節 の成形試験に基づき，冷却速度を $0.155\left[{ }^{\circ} \mathrm{C} / \mathrm{s}\right]$ 一定とし，ガラ ス材が $25\left[{ }^{\circ} \mathrm{C}\right]$ になるまで泠却を行った。

3.3 結果および考察Ｆig.4 に成形高さに及ぼす成形 温度の影響について実験值と解析值とを比較した図を示す。 D263, PYREX のいずれも, 温度が高くなるにつれて成形高 さが増加した。ここで, 本研究にて用いた 2 種類のガラス材料 は, Table 1 に示すと扔り非常に良く似た物性值を有している。 しかしながら，成形結果を比較した場合，PYREXはD263よ りも成形温度を高く設定する必要があることがわかった。つま り，ガラスのマイクロプレスに扔ける成形条件は，単にガラス 転移点などの物性值だけでは判断できず，熱粘弾性特性を考慮 して決定する必要があるといえる。

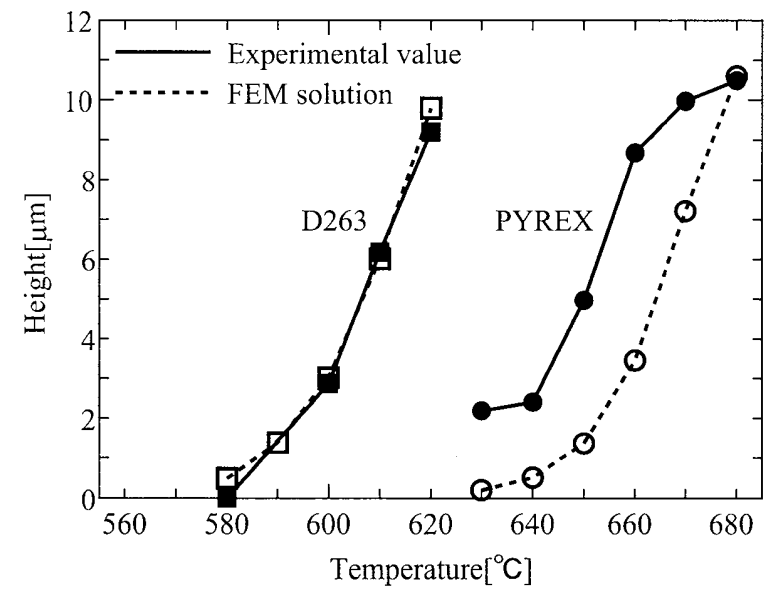

Fig.4 Comparison between analytical value and experimental value
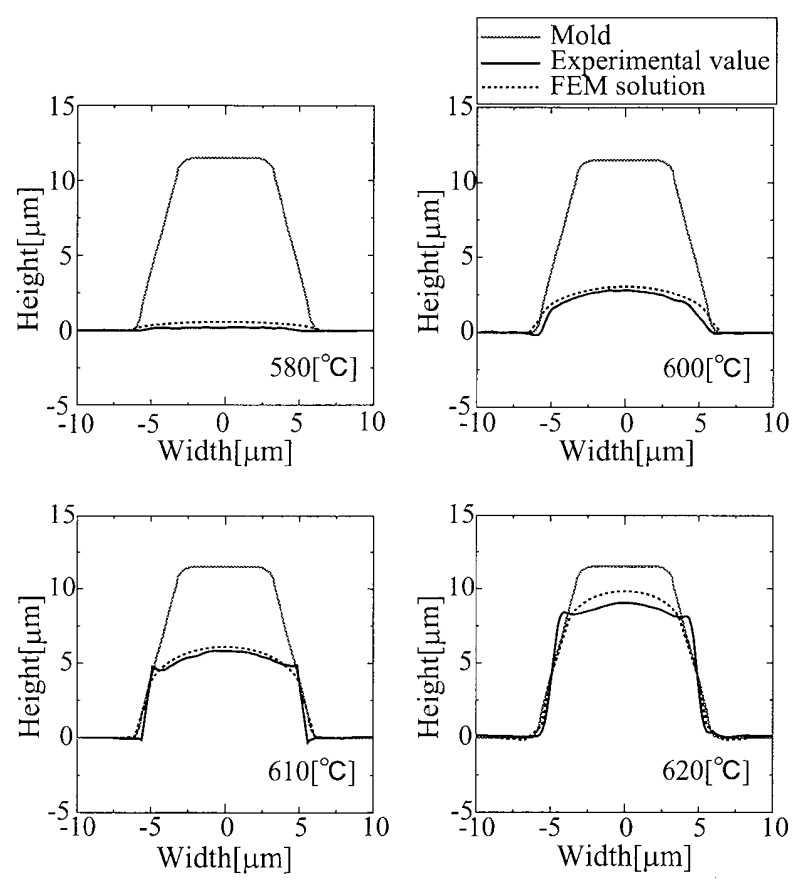

Fig.5 Comparison of shape of test pieces (D263)

次に，実験結果と解析結果との比較を行う。D263について は実験結果と解析結果はほぼ一致しており，解析が非常に高い 精度で行われていることがわかる.Fig.5に，D263における成 形後の溝断面形状および解析結果を示す。これより, 各温度に おける断面形状に関しても実験結果と解析結果は高い精度で一 致していることがわかる.

一方, PYREXに扔いては, 解析值が実験值を最大 $5[\mu \mathrm{m}]$ 程 度下回ってはいるが，成形温度と成形高さの関係は，ほぼ類似 の傾向を示している，PYREXのプレス成形において，実験值 と解析值とで差が確認された原因としては, クリープ試験時の 温度環境の差が举げられる。熱粘弾性特性の温度依存性により, 数 $\mathrm{C}$ の温度差が解析結果に与える影響は小さくないと考えられ る。つまり，実験における熱制御の精度を上げることによって， 実験結果と解析結果の差は小さくなるものと考えられる.

\section{文献}

（1）荒井政大，山本和也，中村淳之介，伊藤䨘明，松倉利顕，杉本公一，有限要 素法によるガラスレンズのプレス成形シミュレーション, 日本機械学会論文 集 A 編, Vol.72, No.717, (2006),pp.683-690. 